\title{
MÔJ POHLAD NA VZÁJOMNÝ VZŤAH ČLOVEKA A PRÍRODY
}

TEODOR MÜNZ, Filozofický ústav Slovenskej akadémie vied v Bratislave, Bratislava, SR

MÜNZ, T.: My Atitude Towards the Relationship Between Man and Nature FILOZOFIA, 75, 2020, No 10, pp. $892-898$

\begin{abstract}
The main problem which the author solves in this essay, is the question, why man (Homo Sapiens) has so much devastated the nature in the Modern Age. His answer is that humans have always been interfering in nature, however, in the Modern Age science has helped them a lot. For a very long time, humans have not been aware of the fact that they are is devastating the nature to a great extent. The nature is sharply reacting to this situation now. It is just only a question of time whether mankind will be able to adjust to this new situation. In this sense, science can really be helpful! If not, man may even perish...
\end{abstract}

Keywords: Man - Nature - Paradox - Good - Evil

O vzt'ahu človeka a prírody som hovoril vo viacerých svojich prácach (Münz 2008; 2015), naposledy v knihe Odchádzame? Esej o človeku a prírode ktorá vyšla začiatkom tohto roka (Münz 2020). Spomenul som však v nej, že moje názory sa menia a podotýkam to aj dnes. Hoci od napísania knihy uplynulo len niečo vyše pol roka, na tento vzt’ah sa pozerám čiastočne inak, hlbšie a systematickejšie. Ale aj zmenene. A tak budem o ňom aj teraz písat'.

Problém tohto vzt'ahu je vel’mi starý, takže nezačínam s ničím novým. Nemením sa však iba ja, ,menia sa aj časy a my sa meníme s nimi“. Čiže otázkou je, ako sa časy od starého riešenia tohto problému zmenili, a teda aj ako my ( $v$ tomto prípade ja) riešime či riešim problém uvedeného vzt'ahu dnes. Každý z nás je rôzny, sme rôznopohl'adoví, ako to nazývam, čiže každý hovorí predovšetkým zo svojho uhla pohl'adu, a to platí aj o mne.

Hovoril som o starom riešení tohto problému, no „staroba“, ktorú mám teraz na mysli, nie je taká vzdialená, ako by sa mohlo zdat'. Ide len o niekol'ko posledných storočí. Všetci vieme, ako sa od začiatku novoveku podnes náš vzt’ah k prírode prudko zmenil, ako sme ju skvárili, spustošili, neživú i živú, čo zlé sme v nej narobili a ako za to začíname tvrdo pykat'. Hrnie sa to na nás zo všetkých strán, aj z tých najmenej očakávaných, a vôbec netušíme, čo všetko nás ešte môže zasiahnut'. Je z toho vel'ký poplach. 
Očividne sme sa aj časovo s prírodou rozišli. Príroda, povedzme, že jej evolúcia, má stále čas, postupuje nebadane, po zlomkoch milimetra, takže máme dojem, že obe strany stoja, nemenia sa. Kol'ko času prírode trvalo, kým vytvorila zo zvierata bytost' iba podobnú človeku, a nieto ešte dnešného človeka?! Státisíce, ba milióny rokov? No my sme sa v posledných troch či štyroch storočiach nielen rozbehli, ale dnes už priam cválame, meníme sa takmer zo dňa na deň, takže to, čo sme urobili pred rokom, je už dávnou minulost'ou. Ale viditel'ne sa meníme len psychicky, kým telo ostáva verné pomalej prírode, akoby sa nemenilo, stálo. Náš duch bol vzbúrencom vždy, on tvoril dejiny a takmer iba on sa do nich aj dostal. Telo takmer nestálo za reč. Ale tiež vykonalo svoje. Aké boli za starých Grékov športové olympiády a aké sú dnes?!

Je prirodzené, že toto všetko nastoluje otázky, ako sa to, čo sa stalo v novoveku, mohlo stat', kde sú príčiny toho, ako sme sa mohli tak utrhnút' a ako to odstránit'. Lebo nás to už ohrozuje aj existenčne, no my chceme žit' a byt', hoci ten svoj život občas aj preklíname, ba sa ho aj dobrovol’ne vzdávame. To je však iba jeden z našich mnohých paradoxov. Odpovede sú rôzne, najčastejšie optimistické, podmienené zrejme vôlou $\mathrm{k}$ životu. Toto nie je prvý prípad, človek už vyčíñal aj dávnejšie, no vždy z toho vybŕdol bez väčších odrenín a prírode to tiež nevadilo. Napokon, nevie ho ničit' aj ona? Nie je dnešný nový koronavírus Covid-19 tiež jej dielom, azda nevie ničit’ aj seba, a to tak, že z predošlého nenechá na sebe za deň, hodinu, ani kameň na kameni? Neničí človeka aj ona rôznymi chorobami, epidémiami, mormi, hladomormi, zemetraseniami, sopkami, meteoritmi a inými vecami? Náš svet je už taký, že bez ničenia a v jeho rámci aj bez zabíjania - sa v ňom nič vel'ké neudeje, je v ňom zakódované nielen vel'ké plus, ale aj mínus, pričom jedno bez druhého nemôže byt'. Nie je to inak ani v človeku, ktorý tiež koná nielen zlo, ale aj dobro. No len pre seba, zatial' čo jeho dobro voči prírode sa doteraz neprejavilo. Príroda bola preňho vel'mi dlho nevyčerpatel'nou zásobárňou životných potrieb a nič za to od neho nežiadala, takže si na to zvykol. Iba zrazu teraz! Čím sa previnil, nekonal tak, ako mal? Človek je však diet’a prírody, jablko sa teda od stromu d’aleko nezakotúl'alo, takže netreba hned' nad ním lámat' palicu, ale treba ho brat' takého, aký je. Cizeluje sa odpradávna a vždy je vycizelovaný tak, ako za daných okolností najlepšie môže byt', a preto aj stále žije.

Toto sú teda odpovede optimistov, ktorí tvrdia, že človek aj túto krízu prežije a že vyzbrojený novými skúsenost'ami bude v budúcnosti opatrnejší, takže bude mat' z krízy aj úžitok. U nás je to už tak, že najprv musíme vyviest' nejaký nezmysel, o ktorom sme, prirodzene, dlho nič nevedeli, a až ked' zistíme, čo zlé sme medzičasom napáchali, usilujeme sa z toho dostat'. Aspoň doteraz to tak bolo a či sa to pod tlakom súčasných udalostí zmení, to je pri nás, nielen revolučných, ale rovnako aj konzervatívnych bytostiach, otázne. A prečo pod tlakom dnešných udalostí? Lebo práve my sme naozaj bohato „obdarení“. Nemáme problémy len s ničením prírody, ale pridal sa 
aj spomínaný koronavírus Covid-19. Sotva ho vytvoril človek, ako sa tiež tvrdí. Vynára sa o ňom aj mnoho úvah, no zrazu nám doterajší život dôkladne zamiešal, a možno ešte aj zamieša. No azda si z neho vezmeme okrem iných poučení aj to, že už budeme na podobnú eventualitu mysliet' a pripravovat' sa na ňu, pokial' sa to len bude dat'. Lebo s budúcnost'ou máme najväčšie problémy. Ustavične do nej vstupujeme, vieme však o nej najmenej. Pritom občas nás tak udrie po hlave, až sa nám zaiskrí v očiach. Pripravujeme si to však sami, ani o tom nevieme, a ked' to príde, situácia nás vydesí. Kde sa to vzalo, čo to má znamenat?! To je náš najväčší paradox.

Č́m sa teda človek vyšvihol tak vysoko nad zviera - alebo upadol podeň -, že dokáže takéto veci? Nazývam to vyčnievaním. Človek sa svojím sebauvedomením, svojím rozumom, svojím ciel'avedomým, úmyselne dobrým či zlým konaním vyšvihol nad zviera, vyčnieva, prečnieva nad ním a všetko, čo si myslí a ako koná, je znakom jeho vyčnievania. Dnes si už uvedomuje, čo na rozdiel od zvierat v prírode i vo svojom spoločenskom živote narobil, lebo si vytvoril schopnost' akoby nad svoj rámec a nevie ju do tohto rámca zase vpratat'. Dozadu sa íst' nedá a dopredu je cesta neznáma. To je jedna z nevýhod práce, na ktorú sa dal v minulosti. Lenže to už predbieham.

Znovu sa teda natíska otázka, čo sa stalo, prečo práve človek prírodu tak zničil, čím sa predsa len líši od svojich zvieracích predkov, čo zlé alebo zlo-dobré má navyše, že toto dokáže?

Prvým, najvypuklejším a dávno známym špecifikom človeka je práca - rozumom podporovaná práca, treba dodat'. Pracujú totiž aj zvieratá (ak nie aj rastliny), nie však za pomoci rozumu, ale inštinktov. Zvieratá, a teda kedysi aj predok človeka, chodili a dodnes chodia „na hotové“. Aj nám z toho ešte čosi zostalo, radi chodíme na huby, na lesné ovocie, na stromové ovocie, o ktoré sa nestaráme, ale z toho by sme nevyžili. Máme vel'ké množstvo vecí, rôznych potrieb, ktoré si musíme zadovážit' prácou. Pracujeme, vybudovali sme si obrovskú materiálnu civilizáciu a v nej duchovnú kultúru, máme nekonečnú del'bu práce, vytvorili sme si svet vo svete. Prirodzene, to všetko bolo možné len vd’aka rozumu, ktorý sa vyvíjal paralelne s prácou, lebo vždy sa vynárala otázka: ako to či ono dosiahnut? A dopyt sa stále zväčšoval. Dnes sa pýšime vel'kými výdobytkami rozumu, ako napríklad vedou, filozofiou a množstvom iných disciplín. Bez rozumu by nebolo ani umenie a vôbec nič z toho, čo konáme.

Rozum sa zrejme vyvinul rozpadom niektorého zvieracieho inštinktu - rozpadom, ktorý však znamenal z jednoty mnohost', $\mathrm{z}$ jednosmernosti mnohosmernost', z istoty neistotu, blúdenie, hladanie, nachádzanie a strácanie, potkýnanie, pády a vstávanie, pravdu aj omyl, ale aj napredovanie, zlepšovanie vedenia, zväčšovanie vedomostí, pokrok.

Pozrime sa z tohto hladiska na zvieratá, ba aj na hmyz. Aj ony pracujú, zadovažujú si potravu, často aj vel'mi komplikovane, aj ony majú „strechu nad hlavou“. Ich 
práca je však inštinktívna, jednosmerná, takmer nediferencovaná, istá a spol'ahlivá, úspešná na prvý raz, hoci niekedy tiež zlyháva. Avšak to sú výnimky, ktoré potvrdzujú pravidlo. „Príbytok“, ktorý si postavia, zväčša vydrží aj pre d’alšie generácie, máločo sa im rúca, padá. A všetko to sa deje v prírode, ktorej to naskrze neškodí, ba tá to ani neregistruje. Noru, ktorú si zviera vyhrabe, zdedia jeho mlád’atá a mlád’atá ich mlád’at, hniezdo, ktoré si lastovičky postavia pod strechou, na budúcu jar spol’ahlivo nájdu a vyvedú z neho d’alšie mladé. A včelia král'ovná z roka na rok vyvádza v tom istom úli nové generácie.

Čo sme však urobili v prírode my?

Staviame si vel'ké domy, ktoré zastarávajú a potom ich renovujeme, lebo architektúra sa mení a treba „držat' krok s pokrokom“. Klčujeme lesy, aby sme mohli stavat', a ked' ani to nestačí, lebo l’udstva pribúda, t’aháme domy do výšky. Rieky regulujeme, popretínali sme ich priehradami, ničíme vodné, zemské, vzdušné živočíšstvo a pomaly už nenechávame ani kameň na kameni. Popretŕhali sme prirodzenú živočíšnu ret’az, ktorá sa tvorila milióny rokov, zničili sme životné prostredie množstva živočíšstva. Máme techniku a už aj techniku na výrobu techniky, a tento zlo-dobrý priatel'-nepriatel' nám vo všetkom pomáha, ale ničí aj nás. Všetko, čo zlé sme doteraz urobili, podkopáva aj nás, takže si možno kopeme jamu, ktorá nás nenávratne pohltí; tak ako sme my jamou, ktorá nenávratne pohltila množstvo živočíšnych druhov. Nemá zmysel rozvádzat' to d’alej, všetci o tom dobre vieme. To sú oproti ostatným živočíšsnym zásahom do prírody vel'ké zmeny, ktoré príroda zaregistrovala, aj na ne reaguje.

$\mathrm{Z}$ toho je jasne vidiet', že my sme svojím rozpadnutým inštinktom, rozumom upadli, že sme voči zvieratám úpadkové tvory; a to nielen na škodu prírody, ale aj nás samých. A sme vel'mi štastní, ak sa nám dlhým cvikom podarí robit’ niečo inštinktívne, to znamená automaticky, bezchybne, dokonale. Vzdialili sme sa od prírody, odcudzili sme sa jej, hoci sme ostali v nej, no prestali sme si s ňou rozumiet'. Donedávna sme počúvali zo strany našich náboženstiev, že náš pôvod je polobožský. Boh nás telesne síce vytvoril z hliny, ale vdýchol do nej svojho ducha. No Darwin to obrátil o stoosemdesiat stupňov: Vytvorila nás len príroda, a to dokonca zo zvierat’a, ktorého stopy sú $\mathrm{z}$ vel'kej časti stále $\mathrm{v}$ nás. Teraz nám príroda nakoniec odpovedá a zráža nás z nášho piedestálu. My ju nezložíme na lopatky, ale ona môže zložit' nás.

Dnes sa o porozumenie s prírodou už snažíme, no len habkavo, rozumom, ktorý je jej cudzí a vel’a naň nedá. Inštinkt pre niekdajšie porozumenie s ňou sme už stratili. Pokúšame sa o návrat $\mathrm{k}$ nej vo vede, no dobre vieme, aká je to práca a ako sa pri nej vieme aj mýlit'. Omyl a chyba sú naši trvalí sprievodcovia, hoci vd’aka aj za ne, lebo ich môžeme odstraňovat', a tak napredovat' a nachádzat' aj lepšie poznatky. Aj to svedčí o tom, že sme deti prírody, hoci už odcudzené. Aj ona v evolúcii opravuje 
a prekonáva všetko chybné a nahrádza lepším. Jej chybou, omylom však môžeme byt' aj my, ako to dokumentujeme v ostatnom čase.

Naše myšlienkové, poznávacie, teraz už cválajúce dejiny a civilizácia a kultúra, ktoré s nimi súvisia, sú z tohto hl'adiska pochybnou záležitost'ou. Ovel’a prirodzenejšie sú dejiny zvieracej práce, ktoré takmer stoja. Dozaista, kam by sa ponáhl'ali? Čím bližšie k ,stojacej“ prírode, tým bližšie k dokonalosti. Ale kam sa to tak ženieme my? Podl'a môjho názoru ku vševedeniu, nazývanému aj vševedúcost'ou či vševedúcnost'ou. Nie preto, aby sme túto vlastnost' pripísali bohu, ako to robíme v náboženstve, ale kvôli sebe samým, aby sme sa konečne vyznali vo svojom živote a unikli zo všetkému toho chaosu, v ktorom sa nachádzame. Ked' to už nejde po starom, lebo inštinkt súžitia s prírodou sme stratili, tak sa o to pokúšame po novom. Vševedenie by nám povedalo, čo a ako.

Ide nám totiž o skutočnost' - o objektívnu, od nás nezávislú skutočnost' -, od ktorej sme sa istým spôsobom odtrhli a ku ktorej sa chceme vrátit', lebo už dobre vieme, čo sme stratili. Zrazu je pre nás vel'kou hodnotou a o jej získanie sa usilujeme. Hl’adá ju veda, hl'adá ju filozofia, hl’adá ju aj umenie, azda všetky naše disciplíny, každá po svojom. Aj bežný život. To je dnes ten najpevnejší bod - či azda jediný pevný bod? -, ktorý hladáme. A konečný, lebo za skutočnost' sa íst' nedá, niet kam. Mat' skutočnost' znamená mat' pevnú oporu, na ktorú sa dá spol'ahnút'. Nemusím tu spomínat', ako sa práve filozofi pokúšali preniknút rôznymi metódami až k nej a dokonca s ňou splývat'. No všetko márne. Nenájdeme ju bezprostredne, nesplynieme $\mathrm{s}$ ňou a jediné a najspol’ahlivejšie, čo máme na to, aby sme sa $\mathrm{k}$ nej aspoň približili, je exaktná veda, jej poznávanie a - rozum. Nikdy však nedôjdeme na koniec, nikdy nezastaneme, nebudeme pri konečnom cieli, pri jej úplnom spoznaní.

Sú tu totiž aj iné príčiny.

Sú len v nás. Už som spomenul, že sme samostatné indivíduá, jedinci, osobití a osobitné bytosti. Ako také máme určitý poznávací, po novom povedané epistemologický, svojráz. Síce každý iný, lebo aj navonok sa navzájom líšime, ale naša rôznost' je teraz zanedbatel'ná. Vieme totiž, že vonkajší svet, teda celú objektívnu skutočnost' nepoznávame tak, ako vyzerá sama osebe, ale tak, ako nám ju sprostredkujú naše poznávacie orgány. O tom, že príroda ako taká vôbec existuje - lebo aj také pochybnosti sa vo filozofii už vynorili -, svedčí fakt, že je čímsi, čo stojí oproti nám ako nezlomná prekážka, čomu nemôžeme ani násilím vnútit' nič, čo v nej nie je, a že len ked’ to rešpektujeme a podl'a toho sa zariadime, je to zase prístupné, viac-menej schval'uje naše názory. Príroda je nám neodvolatel’ne nadriadená, je to prísna monarchistka. Teda jej poznávanie závisí od našich poznávacích orgánov. Na druhej strane tieto orgány sa vytvorili tak, aby sme ju poznávali, lebo sme od nej bytostne existenčne závislí, a o tom, že to dokážeme, svedčí fakt, že sme tu a naše poznávanie sa zlepšuje. 
Výsledok je ten, že síce ju nepoznávame ako takú, osebe, a to pre našu epistemologickú špecifickost', ale len po svojom, no to stačí, aby sme ju vyžili. A už sme dokázali, že sme to aj prehnali a príroda nás už znovu neúprosne koriguje.

Tol'ko nám hovorí biológia, lebo je to v podstate biologická, a nie filozofická záležitost'. Tento stav nás však neuspokojuje. Našej zvedavosti totiž prekáža vyrovnat' sa s ním, lebo sú tu aj zretel'né znaky, že skutočnost' môžeme poznávat' ešte dôkladnejšie a zlepšovat' si tak životné podmienky. No vieme, kol'kí filozofi sa dokonca rôznymi intuíciami o to pokúsili, ale márne, čo tvrdíme preto, lebo vieme, že ich poznatky $\mathrm{o}$ tej istej veci sa rôznili. Intuícia $\mathrm{v}$ tomto zmysle je klam, hoci inak má aj pozitívny význam. O bezprostredné poznávanie skutočnosti sa pokúsila, a stále sa oň pokúša, aj veda. Tiež však márne, nie však intuíciou, ale svojou exaktnost'ou, ktorá znamená dôslednost', presnost', ale nepomáha, hoci veda chce mat', a aj máva pravdu. No pravda neznamená zhodu s nezávislou skutočnost’ou, ako sa to bežne predpokladá. Pravda je časopriestorovo podmienený poznatok o skutočnosti a implikuje omyl. Ked' sa však z nej omyl vykl'uje a zomyl’ní ju, poháňa poznávanie dopredu, $\mathrm{k}$ adekvátnejšej pravde, hoci tiež bez nádeje, že raz dosiahne absolútnu pravdu a že sa celý proces zastaví. Už ten fakt, že tento proces pokračuje, svedčí o tom, že pravda implikuje omyl, teda že nie je zhodná so skutočnost'ou a že skutočnost' ako takú nespoznáme nikdy. Lebo aj ked' budú za nás poznávat' iba prístroje, aj tie budú závisiet' od svojich „orgánov“.

Zlo sa však bez dobra nevynára, a tak sa musíme opýtat', či spomenuté stroskotané filozofické pokusy o bezprostredné spoznanie nezávislej skutočnosti znamenali aj niečo pozitívne. Myslím, že áno.

Filozofi noetici, gnozeológovia oddávna vedeli, že hl'adáme skutočnost' a ich snahu o jej spoznanie môžeme hodnotit' ako príspevok k jej celkovému hl'adaniu. Dodnes nie sú a nebudú na konci, ako tam nebude ani veda, a aj preto si myslím, že veda filozofiu nemôže nahradit', lebo má ten istý problém sama so sebou. Vieme totiž, že sa už aj u nás ozvali hlasy, že špekulujúca filozofia musí zaniknút' a nahradia ju exaktné vedy. Mali by si však najprv urobit' poriadok pred vlastným prahom. Čím väčšia pravda, tým väčší omyl. Také sú vedy, a to aj exaktné. Každé poznávanie chce mat' pravdu, chce končit' tým, že uchopilo skutočnost' a nemá d'alej čo robit'.

V poznávaní teda aj blúdime a hovorí sa, že aj preto, lebo sme stratili mieru. Keby sme vraj žili podl'a miery, boli by sme na tom dobre. Spomeňme si na slávne, dodnes citované Protagorove slová, že „človek je mierou všetkých vecí, existujúcich, že existujú, neexistujúcich, že neexistujú“. Áno, súhlasím, ibaže každý máme svoju odlišnost' a svoju mieru. Kol'ko l'udí, tol'ko mier - a sme zase v l'udskom neporiadku, chaose. A zase tu musím pochválit' zvieratá, lebo ony, vyzerá to tak, túto mieru nestratili a držia sa jej. Ak sa ošípaná vypasie tak, že sa sotva vie pohnút', je to l'udské, či skôr nel’udské dielo, lebo ju chováme na zabitie, ,na slaninu“. Nevidel som ešte 
svojvol'ne vypasenú ošípanú, hoci som mal príležitostí dost'. Pozrime sa však na l’udí! Prichádza nám z toho až zle. Netreba tu čosi obrátit' o stoosemdesiat stupňov, urobit d’alší kopernikovský obrat? Nevychováva tu človek ošípanú preto, aby sa ňou sám stal? Ak aj nie, napriek tomu sa mu to darí vel'mi dobre.

V knihe Odchádzame? som sa na konci prejavil ako pesimista. Človek vo svojom vývoji pracuje nielen proti prírode, ale aj proti sebe, a musí z tejto planéty odíst'. Ak ho nezničí príroda, zničí sa sám, človek proti človeku, a to zničujúcimi zbraňami. Nukleárne zbrane nemáme proti prírode, ale proti sebe navzájom. Hirošimu som nazval začiatkom konca ludstva. Za názov knihy som však dal otáznik. Dnes sa mi situácia javí trochu inak. Človek chce žit' a byt', hoci si už vyrobil množstvo prostriedkov, aby sa mohol vyhubit', a stále sa v tom zdokonal'uje. Je vel'kou otázkou, či chce v tomto trende pokračovat', alebo odbočit'. To odbočenie by bolo totiž vel'mi náročné, lebo by znamenalo v mnohom zmenit' svoj doterajší život, vedený takto odnepamäti. Zamyslime sa nad tým, čo všetko by to znamenalo! Nevyrobit' ani vreckový nožík, nieto ešte kuchynský nôž. Stará skúsenost’ však hovorí, že človek je schopný všetkého, teda aj tejto zmeny, doteraz najväčšej, aká sa od neho kedy žiadala. Nútim sa $\mathrm{k}$ viere, že to vskutku zvládne a prajem mu v tom vel’a síl a úspechov.

\section{Literatúra}

Münz, T. (2008): Hladanie skutočnosti. Bratislava: Kalligram.

Münz, T. (2015): Cesta za skutočnost’ou bez metafyziky: S Nietzschem a proti nemu. Bratislava: Kalligram.

Münz, T. (2020): Odchádzame? Esej o človeku a prírode. Bratislava: Petrus.

Teodor Münz, emeritus Filozofický ústav SAV

Klemensova 1

81364 Bratislava 1

Slovenská republika

e-mail: teodor.munz@gmail.com

ORCID ID: https://orcid.org/0000-0003-3604-7006 